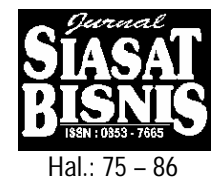

\title{
PENILAIAN KEBUTUHAN PELATIHAN: TANTANGAN DAN SOLUSI*)
}

\author{
Retno Wulandari \\ STIE YKPN Yogyakarta
}

\begin{abstract}
Abstrak
Persaingan mendorong organisasi agar selalu meningkatkan kinerjanya, sehingga dicapai keunggulan bersaing. Salah satu langkah yang ditempuh adalah dengan mengadakan pelatihan dan pengembangan karyawan secara ekstensif dan kontinyu. Penilaian kebutuhan pelatihan (training need assessment) merupakan langkah strategis untuk mengetahui program pelatihan yang tepat bagi organisasi dan karyawan. Selain itu, untuk menghasilkan pelatihan yang efektif, para professional pelatihan perlu menekankan doing the right things the first time.
\end{abstract}

Kata kunci: Kinerja, keunggulan bersaing, dan penilaian kebutuhan pelatihan.

PENDAHULUAN

Persaingan telah mendorong organisasi agar selalu meningkatkan kinerja organisasi. Organisasi berusaha mencapai keunggulan bersaing dengan memaksimumkan kemampuan seluruh anggota organisasi ini. Kondisi ini menyadarkan para manajer bahwa pelatihan karyawan merupakan kebutuhan yang tak dapat ditunda. Telah diakui oleh para manajer organisasi bahwa kemajuan suatu organisasi tergantung dari pengembangan sumber daya manusia dan diyakini pula bahwa kinerja karyawan dapat ditingkatkan. Suatu tantangan dan kesempatan bagi manajer sumber daya manusia dan para professional pelatihan untuk membantu organisasi agar mampu berkompetisi dan responsive dalam lingkungan yang berubah cepat.

Seringkali manajer mengabaikan langkah penting dalam penentuan pelatihan. Penilaian kebutuhan pelatihan yang merupakan bagian integral program pelatihan kurang menjadi perhatian utama. Organisasi perlu menentukan secara tepat kebutuhan pelatihan. Agar penggunaan biaya pelatihan dan sumber lain efektif, langkah awal yang perlu diperhatikan adalah lokasi, scope, dan tingkat kepentingannya.

Penilaian kebutuhan pelatihan (training need assessment) merupakan langkah strategis untuk mengetahui program pelatihan yang tepat bagi organisasi dan karyawan. Penilaian kebutuhan pelatihan sangat penting karena menyediakan informasi mengenai tingkat keahlian (skill) dan pengetahuan (knowledge) sumber daya manusia organisasi. Dengan informasi ini, manajer dapat mengetahui gap antara kebutuhan organisasi dan kapabilitas karyawan. Pelatihan yang diselenggarakan dapat difokuskan untuk mengisi gap tersebut.

*) Pernah diterbitkan pada Jurnal Siasat Bisnis edisi Th. I, Vol. 5 Nopember 1997 
Makalah ini akan membahas bagaimana organisasi menetapkan program pelatihan. Penilaian atau analisis kebutuhan merupakan cara yang dapat membantu meyakinkan manajemen bahwa program pelatihan yang akan diimplementasikan adalah tepat.

\section{MENGAPA PELATIHAN BELUM MENGATASI MASALAH?}

Sering manajer kecewa terhadap hasil pelatihan karena investasi yang telah banyak dikeluarkan untuk program pelatihan tidak memberi kemajuan ataupun perubahan bagi organisasi. Tidak semua hasil penyelenggaraan pelatihan sesuai dengan tujuan yang diharapkan. Investasi yang dikeluarkan untuk program pelatihan akan sia-sia jika pelatihan gagal menghasilkan kontribusi terhadap tujuan organisasi (Fisher, 1992).

Customers departemen sumber daya manusia ataupun departemen pelatihan dan pengembangan seringkali menyatakan ketidakpuasannya terhadap hasil program pelatihan. Para manajer lini maupun manajer unit bisnis memandang bahwa aktivitas pelatihan yang diberikan dianggap sebagai "training for training's sake" dan "doing comfortable things" (Macintosh, 1993). Dengan kata lain, pelatihan yang diterima karyawan tidak sesuai dengan kebutuhan actual. Departemen pelatihan dan pengembangan yang aktivitasnya diperlukan untuk terjadinya suatu perubahan belum mampu sepenuhnya merealisasi tujuan yang hendak dicapai. Tentu saja tanpa penentuan kebutuhan pelatihan yang jelas, prioritas yang ingin dicapai tidak dapat terpenuhi.

Kegagalan juga diakibatkan karena diabaikannya perencanaan strategic organisasi ketika menentukan pelatihan. Tidak ada hubungan yang jelas antara perencanaan organisasi dengan keputusan kebutuhan pelatihan. Usaha pengembangan sumber daya manusia yang efektif tentu saja perlu disesuaikan dengan rencana strategic organisasi. Freeman (1993) menegaskan bahwa pengembangan sumber daya manusia harus diintegrasikan dengan perencanaan strategic organisasi. Pelatihan yang merupakan usaha organisasi mengembangkan kompetensi anggota organisasi dalam melakukan aktivitas-aktivitas pekerjaan tidak dapat diselenggarakan terpisah dari perencanaan bisnis strategik. Selain dapat menghasilkan kompetensi dan efektivitas unit operasional, pelatihan diharapkan pula dapat menghadapi realitas dan tantangan organisasi di masa yang akan datang (Haywood, 1992). Sebagai bagian dari perencanaan strategic tersebut maka organisasi harus secara terstruktur menganalisis sumber daya manusia, apa yang dibutuhkan saat ini dan yang akan datang untuk mencapai tujuan organisasi.

Secara jelas dikemukakan bahwa pelatihan diselenggarakan bertujuan untuk membantu organisasi dapat bersaing secara efektif saat ini 
dan yang akan datang. Untuk memenuhi tujuan tersebut maka penentuan program pelatihan tidak lepas dari rencana strategic. Tentu saja untuk menghadapi realitas dan tantangan di masa yang akan datang tidak mudah. Sebagai strategic leader (Sleezer, 1993), para praktisi sumber daya manusia harus dapat menganalisis kebutuhan yang secara akurat dapat menilai kebutuhan kinerja organisasi sehingga pelatihan yang diselenggarakan akan relevan dengan pekerjaan karyawan dan tujuan organisasi secara keseluruhan.

\section{PERLUNYA METODE FORMAL}

Seringkali manajemen memutuskan untuk mengadakan pelatihan tanpa menganalisis dahulu kebutuhan organisasi, pekerjaan, dan karyawan. Penelitian Mahler dan Monroe mengenai penentuan kebutuhan pelatihan dalam suatu industri menemukan bahwa metode yang paling sering digunakan dalam penentuan kebutuhan pelatihan adalah metode informal. Penelitian menunjukkan bahwa hanya sekitar satu di antara sepuluh perusahaan menggunakan pendekatan sistematis dalam menentukan kebutuhan pelatihan (Moore, 1978). Hasil penelitian lain menunjukkan juga bahwa kurang dari sepertiga perusahaan-perusahaan di United State menyelenggarakan penilaian kebutuhan untuk menentukan pelatihan dan pengembangan karyawan (Saari, 1988). Dari sejumlah perusahaan yang mengadakan penilaian kebutuhan tersebut, sebagian besar adalah perusahaanperusahaan besar dan hanya sebagian kecil saja perusahaan-perusahaan kecil melakukan penilaian kebutuhan akan pelatihan.

Fenomena tersebut menggambarkan bahwa sebagian besar perusahaan menyelenggarakan program pelatihan tanpa melalui tahap penilaian. Para ahli menyatakan bahwa tanpa diawali dengan menentukan kebutuhan, tidak dapat dijamin bahwa pelatihan yang tepat akan diberikan pada trainee yang tepat. Pelatihan dikatakan berhasil jika dapat merespon pada masalah yang tepat. Banyak program pelatihan gagal karena masalah pelatihan tidak diidentifikasi secara tepat. Hal ini biasa terjadi jika manajer mendasarkan pelatihan pada "felling" bukan pada fakta yang ada (Carolan, 1993). Jadi, kebutuhan akan pelatihan hanya dapat diketahui secara pasti dari suatu investigasi.

\section{PENILAIAN KEBUTUHAN SEBAGAI LANGKAH STRATEGIS}

Penilaian kebutuhan merupakan langkah awal sebelum mengadakan program pelatihan dan cara penting untuk mengalokasikan pelatihan secara efektif (Schuler, 1993). Untuk menghasilkan program pelatihan yang tepat harus didasari langkah awal yang tepat. Selain sebagai dasar me- 
nentukan pelatihan, penilaian kebutuhan juga menyediakan ukuran untuk mengantisipasi masalah-masalah yang akan datang (Cline, 1993).

Ibaratnya dokter, seorang dokter tidak akan mengobati pasien sampai dia mengetahui apa yang menyebabkan penyakit dan apa yang diperlukan untuk mengatasi penyakit tersebut. Manajemen tidak dapat menentukan pelatihan begitu saja tanpa menganalisis dahulu kebutuhan dan tujuan apa yang ingin dicapai. Penilaian kebutuhan merupakan "road map" untuk mencapai tujuan yang ditetapkan (Doliver, 1993). Penentuan program pelatihan yang tepat bagi karyawan akan memberi nilai bagi organisasi sebagai hasil yang dicapai dari program pelatihan tersebut.

Ada tiga tahap penilaian kebutuhan untuk mengidentifikasi kebutuhan pelatihan, yaitu analisis organisasi, analisis operasi, dan analisa individu (Cascio, 1992; Schuler, 1993).

\section{Analisis Organisasi}

Analisis organisasi menentukan dimana pelatihan dapat dilakukan dan dimana seharusnya dilakukan di dalam organisasi. Analisis ini memfokuskan pada organisasi secara keseluruhan, antara lain mencakup analisis tujuan organisasi, analisis sumber daya, analisis efisiensi, dan analisis iklim organisasi.

Pada tingkat organisasi, kebutuhan pelatihan harus dianalisis sesuai dengan tujuan dan strategi organisasi. Jika hal ini tidak dilakukan, waktu dan biaya untuk penyelenggaraan program akan sia-sia dan tujuan tidak tercapai. Sebagai contoh, ada kemungkinan karyawan dilatih untuk mempunyai keahlian tertentu yang sebenarnya telah mereka kuasai. Karyawan hanya belajar sedikit dari program yang diikuti. Keahlian ataupun pengetahuan yang diberikan tidak memenuhi kebutuhan actual karyawan dan organisasi. Dengan demikian, biaya pelatihan yang dikeluarkan tidak akan bermanfaat selama periode pelatihan tersebut.

Analisis lingkungan eksternal dan internal organisasi juga sangat penting. Analisis ini perlu untuk memperoleh informasi misalnya trend strategi bisnis, produktivitas, absensi, tumover, dan perilaku karyawan di tempat kerja. Informasi ini berguna bagi penentuan tujuan pelatihan yang hendak dicapai. Pertanyaan penting yang muncul yaitu "Apakah pelatihan akan menghasilkan perubahan perilaku karyawan dan akan memberi kontribusi pada tujuan organisasi?"

Sebagai tahap awal berarti perlu adanya upaya mengkaitkan penilaian kebuuthan pelatihan dengan pencapaian tujuan organisasi. Dengan mengkaitkan hubungan tersebut, kebutuhan pelatihan akan dapat diidentifikasi. Tanpa mengetahui tujuan organisasi, organisasi tidak dapat menentukan perlu tidaknya pelatihan. 


\section{Analisis Operasi}

Analisis operasi menentukan bagaimana karyawan melakukan suatu pekerjaan. Tujuan analisis ini adalah untuk menentukan apa yang seharusnya diberikan kepada karyawan agar karyawan dapat melakukan pekerjaan sesuai dengan tingkat yang ingin dicapai. Analisis operasi memerlukan pengujian secara hati-hati pekerjaan yang harus ditampilkan setelah pelaksanaan pelatihan. Analisis ini mencakup:

1) pengumpulan informasi secara sistematis yang menggambarkan secara tepat bagaimana suatu pekerjaan atau kelompok pekerjaan dilakukan.

2) penentuan standar kinerja (performance) untuk suatu pekerjaan.

3) Penentuan bagaimana pekerjaan harus dilakukan untuk memenuhi standar tersebut.

4) Penentuan pengetahuan, keahlian, kemampuan, dan karakteristik lain yang diperlukan untuk suatu kinerja yang efektif.

\section{Analisis Individu}

Analisis ketiga adalah analisis individu. Analisis ini diperlukan untuk mengetahui bagaimana kinerja setiap karyawan ketika melakukan pekerjaan. Pada tahap ini kebutuhan pelatihan setiap karyawan ditentukan. Perbedaan antara kinerja yang diinginkan dengan kinerja yang sesungguhnya merupakan kebutuhan pelatihan bagi individu. Kinerja standar yang telah ditetapkan pada tingkat operasi merupakan kinerja yang ingin dicapai. Sedangkan informasi mengenai kinerja actual karyawan dapat diperoleh dari data kinerja individu, penilaian supervisor, attitude survey, wawancara, dan sebagainya. Kesenjangan antara kinerja actual dan kinerja yang ingin dicapai akan diisi dengan pelatihan.

Dari tahap-tahap analisis tersebut dapat dikatakan bahwa analisis organisasi merupakan dasar untuk melakukan analisis operasi, dan analisis operasi sebagai dasar analisis individu. Ketiga analisis kebutuhan pelatihan tersebut harus dilakukan secara terintegrasi. Kerugian yang diperoleh jika program pelatihan tidak terkoordinasi dengan tujuan dan sasaran organisasi adalah waktu dan biaya banyak dikeluarkan tanpa menghasilkan peningkatan kinerja.

\section{KEBUTUHAN PELATIHAN: DASAR TEORITIS}

Definisi mengenai kebutuhan pelatihan telah disepakati oleh sebagian besar para ahli (Moore, 1978, Schuler, 1993). Untuk menentukan kebutuhan dapat diperoleh dari persamaan berikut ini: kinerja standar- kinerja aktual= kebutuhan pelatihan. Ini berarti perbedaan antara kinerja yang ingin dicapai dengan kinerja sesungguhnya merupakan kebutuhan pelatihan. 
Pada umumnya manajer akan dengan cepat memutuskan untuk mengadakan pelatihan jika diketahui adanya kesenjangan kinerja tersebut. Akan tetapi yang perlu diperhatikan adalah perbedaan kinerja tidak dapat begitu saja diinterpretasikan sebagai problem pelatihan dan tidak harus diatasi dengan pemberian pelatihan. Untuk melihat apakah perbedaan tersebut merupakan problem pelatihan perlu mengetahui secara pasti apakah perbedaan tersebut disebabkan oleh skill deficiency.

Ada empat ketentuan yang menjadi dasar pengidentifikasian kebutuhan pelatihan (Moore, 1978). Ketentuan pertama merupakan definisi yang telah disebutkan sebelumnya, yaitu $D=M-I$, dimana $D=$ Deficiency, M = Mastery, dan I = Initial Skill. Tujuan ketentuan pertama ini adalah untuk menghindari ditetapkannya tujuan-tujuan instruksional pelatihan yang tidak diperlukan dan menghindari pemberian program yang sebenarnya telah dikuasai karyawan.

Ketentuan kedua adalah organisasi perlu mengetahui value yang akan diperoleh dari program pelatihan. Nilai hasil ditunjukkan oleh karyawan merupakan nilai yang telah diperoleh dari pelatihan tersebut. Organisasi perlu memperhatikan value yang akan diperoleh dan bukan sekedar apa yang dipelajari.

Ketentuan ketiga adalah organisasi perlu mengetahui secara pasti bahwa kebutuhan pelatihan memang karena pengetahuan karyawan tidak memadai. Seringkali dijumpai adanya ketidakmampuan dalam kegiatan bisnis yang disebabkan bukan karena pengetahuan karyawan yang tidak memadai akan tetapi disebabkan oleh kondisi lain. Kinerja buruk dapat terjadi antara lain karena kurangnya umpan balik, kurang motivasi, tugas yang tidak jelas, dan mungkin juga karena sanksi yang diberikan.

Ketentuan keempat dalam penentuan kebutuhan pelatihan adalah urutan prioritas. Dari beberapa kebutuhan yang diinvestigasi, tentu ada kebutuhan yang lebih penting dari yang lain. Penentuan prioritas ini dapat diperoleh dari $\mathrm{P}=\mathrm{VN} / \mathrm{C}$, dimana $\mathrm{P}=$ Prioritas, $\mathrm{V}=$ Value, $\mathrm{N}=$ jumlah orang yang diberi pelatihan, dan $C=$ biaya. Penentuan prioritas ini dilakukan karena pertimbangan nilai yang diperoleh dan biaya tertentu yang diinvestasikan.

\section{PENDEKATAN SISTEMATIS PENILAIAN}

\section{Kebutuhan Pelatihan}

Dari pembahasan di atas maka penilaian kebutuhan pelatihan merupakan cara untuk mengidentifikasikan nilai maksimum yang akan diperoleh dari investasi yang dikeluarkan untuk pelatihan dan pengembangan. Bagaimana departemen sumber daya manusia melakukan proses penilaian kebutuhan tersebut? McClelland (1992) mengemukakan pende- 
katan sistem untuk menentukan kebutuhan pelatihan ini. Pendekatan ini merupakan cara yang konsisten dan fleksibel untuk menganalisis sumber daya manusia organisasi. Perusahaan dapat menghemat waktu, dana, dan usaha untuk mengatasi masalah yang tepat. Cara ini merupakan cara efisien untuk memenuhi kebutuhan keahlian dan pengetahuan serta dapat mengatasi perubahan di masa yang akan datang. Lebih lanjut, pendekatan ini menggambarkan bagaimana proses penilaian tersebut terintegrasi ke dalam rencana strategic organisasi.

Pendekatan sistem penentuan kebutuhan pelatihan merupakan prosedur atau komponen yang saling berkaitan satu sama lain. Ada tujuh tahap untuk melakukan penilaian kebutuhan tersebut.

\section{Menentukan Siapa yang Melakukan Penilaian}

Organisasi besar biasanya mempunyai staf yang berpengalaman dalam penilaian kebutuhan pelatihan. Dengan keterbatasan kemampuannya para manajer lini organisasi yang ingin melakukan penilaian akan meminta bantuan pada para professional ini. Organisasi kecil dan tidak mempunyai staf pengembangan sumber daya manusia biasanya akan mencari bantuan konsultan eksternal.

Ada segi positif dan negatif jika menggunakan konsultan eksternal. Segi positifnya antara lain adalah para konsultan eksternal biasanya mempunyai posisi netral dalam melakukan penilaian dan tidak akan mempertimbangkan hal lain selain hasil penilaian tersebut. Konsultan eksternal tidak dapat dipengaruhi oleh kultur organisasi. Konsultan eksternal relatif tidak bisa dalam menghasilkan penilaian dan tidak terpengaruh oleh kondisi politik internal ataupun pengaruh-pengaruh lain. antara lain:

Di sisi lain, penggunaan konsultan ini mempunyai segi negatif,

- Biaya untuk konsultan eksternal biasanya lebih mahal dibanding jika menggunakan tenaga ahli internal.

- Manajer pengembangan sumber daya manusia merasa kehilangan kontrol jika menggunakan konsultan.

- Manajer atas mungki akan menolak membuka organisasi untuk suatu pengamatan yang lebih teliti yang dilakukan oleh konsultan eksternal.

\section{Mendefinisikan Tujuan Penilaian}

Tahap berikutnya adalah mendefinisikan secara selektif tujuan penilaian. Tujuan penilaian harus jelas. Tujuan penilaian merupakan referensi bagi seluruh tahap dalam proses ini. Data yang dihasilkan harus merupakan cerminan langsung tujuan yang telah ditetapkan dalam penilaian ini. 


\section{Memperoleh Komitmen Manajemen}

Penilaian kebutuhan ini akan gagal sejak awal jika tidak ada komitmen, kepercayaan, dan dukungan dari manajemen. Untuk memperoleh komitmen dari manajer maka tujuan penilaian ditentukan secara spesifik.

\section{Memilih Metodologi yang tepat}

Berbagai metode dan teknik dapat diterapkan untuk menilai kebutuhan pelatihan. Metode-metode tersebut antara lain adalah survai, observasi umum, wawancara individu, focus group (McClelland, 1993) dan data performance appraisal (Umiker, 1990). Metode yang dipilih hendaknya sesuai dengan kultur dan struktur organisasi. Sebagai contoh, di dalam organisasi besar mungkin lebih baik menggunakan survai tertulis dan wawancara individu. Untuk organisasi yang lebih kecil, penggunaan wawancara dan focus group mungkin lebih baik.

Beberapa elemen penting yang dapat dipertimbangkan dalam metodologi penilaian ini adalah:

口 Tingkat ketepatan yang diperlukan

- Waktu yang diperlukan untuk mengadakan penilaian

- Ketersediaan sumber daya manusia yang berpengalaman (internal maupun eksternal) untuk mengadakan penilaian.

- Faktor biaya, baik menggunakan sumber eksternal ataupun sumber internal.

- Kemampuan untuk melakukan survai dan wawancara secara rahasia.

\section{a. Survai}

Survai merupakan cara yang sering dilakukan untuk mengumpulkan data. Dari survai dapat diperoleh data yang kemudian dibuat tabulasinya dan dianalisis. Pertanyaan survai harus diperhatikan agar terhindar dari umpan balik yang bias. Pertanyaan survai harus benar sehingga tidak terjadi interpretasi yang keliru dari para responden. Keuntungan penggunaan metode ini adalah: 1) dapat diterapkan pada populasi yang besar, 2) cara yang mudah dalam memperoleh feedback, 3) bias dapat diminimumkan, dan 4) mengisi kuesioner relatif mudah.

\section{b. Observasi Umum}

Kebutuhan pelatihan dapat pula ditentukan melalui teknik observasi. Observasi sangat baik digunakan jika terdapat keterbatasan sumber daya untuk mengadakan penilaian dan jika kelompok atau proses yang akan diobservasi terlalu besar dan kompleks. Observasi hendaknya dilakukan oleh orang yang terlatih dalam teknik observasi dan juga yang mengenal prosedur atau proses yang diobservasi.

\section{c. Wawancara Individu}

Wawancara individu biasanya digunakan bersama dengan survai tertulis, meskipun demikian dapat juga digunakan secara independen. 
Wawancara individu dapat juga ditujukan untuk mengetahui valid tidaknya umpan balik tertulis yang diperoleh dari survai. Wawancara dapat menyediakan informasi tambahan berkaitan dengan hal yang sedang dianalisis.

Keuntungan menggunakan wawancara adalah kesempatan untuk mengadakan interaksi secara langsung antara analis pengembangan sumber daya manusia dengan individu yang kebutuhan pelatihannya sedang dipertimbangkan. Wawancara individu merupakan cara paling efektif untuk mengumpulkan data dan menghasilkan data yang lengkap. Pengalaman telah menunjukkan bahwa banyak karyawan tidak suka diwawancara. Orang akan merasa pekerjaan dan posisinya terancam. Oleh karenanya, pada saat wawancara perlu diciptakan suasana seolah-olah karyawan tersebut sedang tidak diteliti. Tentu saja perlu analis yang berpengalaman dalam hal wawancara ini.

\section{d. Focus Groups}

Focus group ini mirip dengan konsep quality circle (QC). Bedanya adalah kelompok ini digunakan untuk mengadakan brainstorming mengenai hal tertentu sedangkan QC digunakan untuk mengidentifikasi masalah dan menentukan proses untuk mengatasi masalah tersebut. Kelompok ini digunakan untuk menyelidiki alasan atau peristiwa yang telah membentuk impresi kelompok tersebut. Data yang diperoleh dari cara ini akan berupa data kualitatif.

Kelemahan penggunaan kelompok ini adalah biaya yang besar. Biaya yang dikeluarkan antara lain untuk mengadakan pertemuan reguler dan juga apabila anggota kelompok berasal dari daerah yang berbeda. Meskipun biaya penyelenggaraan besar, kelompok ini menyediakan informasi yang berguna sebagai dasar investigasi lebih lanjut melalui survai atau wawancara.

\section{e. Performance Appraisal}

Dari suatu survai pada perusahaan-perusahaan yang telah memenangkan National Training Awards, diketahui bahwa 11 dari 13 perusahaan mengkaitkan kebutuhan pelatihan dengan penilaian kinerja. Enam dari sebelas perusahaan tersebut mempertimbangkan laporan penilaian kinerja sebagai alat utama untuk mengidentifikasi kebutuhan pelatihan (Sloman, 1993). Suatu studi telah dilaksanakan untuk menentukan apakah analisis laporan kinerja berguna untuk menilai kebutuhan pelatihan manajemen (Umiker, 1990). Hasil studi menunjukkan bahwa laporan penilaian kinerja sangat berguna dalam menentukan kebutuhan pelatihan. Yang perlu diperhatikan jika menggunakan laporan ini adalah form penilaian harus terstruktur dan manajer harus terampil dalam proses menilai kinerja. 


\section{Mengadministrasi dan Mengendalikan Penilaian}

Parameter-parameter untuk mengadministrasi dan mengendalikan penilaian ini harus ditentukan sebelumnya. Parameter-parameter tersebut antara lain adalah pengumpulan instrumen survai, tabulasi data, penjadwalan wawancara individu, penentuan biaya, dukungan administrasi, dan kesepakatan ketepatan skedul. Administrasi sejak awal harus jelas jika menggunakan konsultan eksternal dan demikian pula penentuan tanggung jawab setiap individu. Perencanaan yang matang sejak awal akan membantu kelancaran penilaian tersebut.

\section{Menganalisis Hasil}

Analisis data dan umpan balik merupakan proses yang harus dilakukan secara hati-hati. Interpretasi harus dilakukan dengan benar. Judgement awal harus dihindari sampai seluruh data dikumpulkan. Hal ini sangat penting agar tidak mempengaruhi sudut pandang analis dan obyektivitas analisis tersebut.

Jika menggunakan survai, keputusan mengenai bagaimana mengatasi survai yang tidak lengkap dan jawaban yang rancu harus ditentukan di awal penilaian. Jika survai tertulis digunakan dan tabulasi respon dilakukan dengan menggunakan komputer, maka perlu perhatian pada proses memasukkan data. Analisis data yang berupa narasi yang diperoleh dari focus group dan wawancara memerlukan analisis yang hati-hati.

Tujuan penilaian perlu diperhatikan sehingga hanya informasi yang berkaitan langsung dengan tujuan tersebut yang terutama diperhatikan. Informasi tambahan menjadi pertimbangan kedua. Sebagai contoh, apabila diasumsikan bahwa tujuan utama penilaian kebutuhan adalah "untuk mengidentifikasi karyawan yang memerlukan pelatihan interpersonal skill', maka informasi mengenai communication skill mungkin relevan tetapi tidak langsung berkaitan dengan tujuan utama.

Hal lain yang perlu ditekankan adalah menjaga kondisi kenetralan ketika menganalisis hasil. Seringkali sulit untuk mencegah interpretasi pribadi mengenai informasi, tetapi pengaruh tersebut harus diminimumkan agar interpretasi dan analisis data dapat dilakukan secara tepat.

\section{Mempresentasikan kepada Manajer Puncak}

Setelah analisis data selesai, rekomendasi dapat dibuat dan dipresentasikan kepada manajer. Rekomendasi hasil penilaian ini mencakup tujuan, profil kelompok pelatihan, durasi, biaya, dan metode evaluasi. Rekomendasi dibuat berdasarkan hasil perbandingan prioritas-prioritas yang perlu dilakukan secara hati-hati. 


\section{PENUTUP}

Untuk memperoleh keunggulan bersaing, salah satu kunci praktik manajemen sumber daya manusia adalah mengadakan pelatihan dan pengembangan karyawan secara ekstensif dan kontinyu. Pelatihan dan pengembangan yang diselenggarakan perlu terencana dan sistematis (Schuler, 1987). Pendekatan sistem merupakan cara yang tepat untuk mengidentifikasi dan memprediksi keahlian dan pengetahuan yang diperlukan di masa yang akan datang. Kemampuan ini menjadikan organisasi dapat merencanakan pelatihan secara konsisten dan realistis. Pendekatan ini dapat digunakan sebagai dasar penentuan kebutuhan pelatihan secara efisien. Hasil pelatihan yang tidak memuaskan mendorong organisasi untuk mengevaluasi kembali proses penentuan program pelatihan.

Pelatihan dikatakan berhasil jika dapat merespon kebutuhan atau masalah tertentu suatu organisasi. Penilaian kebutuhan pelatihan digunakan oleh departemen sumber daya manusia ataupun departemen pelatihan dan pengembangan untuk mengidentifikasi kebutuhan pelatihan organisasi maupun individu. Penilaian ini memberikan gambaran mengenai keahlian dan pengetahuan organisasi yang dapat dijadikan referensi untuk melihat kebutuhan pelatihan maupun bentuk-bentuk pengembangan yang lain yang diperlukan.

Dengan melakukan penilaian kebutuhan, penentuan pelatihan yang keliru yang merupakan penyebab kegagalan pelatihan akan segera dapat diantisipasi sebelumnya. Dengan mengidentifikasi kebutuhan, baik masalah-masalah actual maupun potensial, organisasi dapat menghemat biaya dan waktu dalam usaha pengembangan sumber daya manusia organisasi. Tentu saja, untuk menghasilkan pelatihan yang efektif, para professional pelatihan perlu menekankan doing the right things the first time.

\section{DAFTAR PUSTAKA}

Cascio, Wayne F., Managing Human Resources: Productivity, Quality of Work Life, Profit, edisi internasional, New York: McGraw-Hill, Inc., 1992, hal. 232-238.

Carolan, Mary D., "Seven Steps for Back-to-Basics Training, Nineties Style", Training \& Development, August, 1993, hal. 15-17.

Cline, Erik B., \& Pennie S. Seibert, "Help for First-Time Needs Assessors", Training \& Development, May, 1993, hal. 99-101.

Dolliver, Sarah K., "To Train or Not To Train? ...An Essential Question", Supervision, October, 1993, hal. 12-15. 
Fisher, Steven A. \& Gary B. Frank, "Gaining the Most from Your Training Dollars: A System Approach to Staff," National Public Accountant, March, 1992, hal. 18-21.

Freeman, Jean M., "Human Resource Planning-Training Needs Analysis", Management Quarterly, Fall, 1993, hal. 32-42.

Haywood, Michael K., "Effective Training: Toward a Strategic Approach", The Cornell H.R.A. Quarterly, December 1992, hal. 43-52.

McClelland, Samuel, "A System Approach to Need Assessment", Training and Development, August 1992, hal. 51-53.

McClelland, Samuel, "A Systematic Training Needs", IM, July/August, 1993, hal. 15-18.

McIntosh, Stephen S., Susan Page, dan Kenneth B. Hall, "Adding Value Throuh Training", Training \& Development, July, 1993, hal. 39-44.

Moore, Michael L. \& Philip Dutton, "Training Needs Analysis: Review and Critique", Academy of Management Review, (3-3), 1978, hal. 301315.

Saari, Lise M., Terry R. Johnson, Steven, D. McLaughlin, dan Denise M. Zimmerle, "A Survey of Management Training and Education Practices in U.S. Companies", Personnel Psychology, Winter, 1988, hal. 731-743.

Schuler, Randall S. dan Susan E. Jackson, "Linking Competitive Strategies whith Human Resource Management Practices", The Academy of Management Executive, August, 1987, hal 207-219.

Schuler, Randal S. \& Vandra L. Huber, Personnel and Human Resource Management, edisi kelima, New York: West Publishing Company, 1993, hal. 511-520.

Sleezer, Chaterine M., "Tried and True Performance Analysis", Training and Development, November 1993, hal. 52-54.

Sloman, Martyn, "Training to Play a Lead Role", Personnel Management, July 1993, hal. 40-45.

Umiker, William \& Thomas Conlin, "Assessing the Need for Supervisory Training: Use of Performance Appraissal", Health Care Supervisor, January, 1990, hal. 40-45. 